\title{
Impact of Micro-Credit on Poor Households in Kurigram District
}

\author{
Md. Thuhid Noor ${ }^{1}$, Md. Rabiul Auwul' ${ }^{2}$, Saha Forid ${ }^{3}$ \\ ${ }^{1}$ Department of Economics, Southeast University, Dhaka, Bangladesh \\ ${ }^{2}$ Graduate Student, Department of Statistics, Begum Rokeya University, Rangpur, Bangladesh \\ ${ }^{3}$ Project Coordinator, Gender Based Violence in Emergency Project, MUKTI Cox's Bazar, Bangladesh \\ Correspondence: Md. Thuhid Noor, Lecturer, Department of Economics, Southeast University, Dhaka, Bangladesh.
}

Received: November 3, $2017 \quad$ Accepted: November 22, $2017 \quad$ Available online: January 1, 2018

doi:10.11114/aef.v5i1.2905

URL: https://doi.org/10.11114/aef.v5i1.2905

\begin{abstract}
This paper aims to examine empirically the impact of micro-credit and the living standard of poor people in former enclaves. People of the former enclave economy, like all developing economies, live in rural areas and their living standard are not good. Therefore, the need to improve the living standard of those areas gave birth to the establishment of the Micro-credit organizations in Bangladesh. These organizations targeted low income clients through giving loans and other facilities like savings, insurance, and transfer services to poor low-income households and micro enterprises. Dashier Chara, one of the deprived regions in all former enclaves, was selected to study the impact of Micro credit activities and the living standard of poor people in the area. Primary sources of data collection method were used, and structured schedule also used in the study. The main finding was that the impact of micro credit has contributed positively to improve the living standard of poor people. The contribution was evident in improving their property acquired, housing conditions, livelihood improvement, their income, and subsequently led to good health and education for their families, acquisition of assets. Based on the findings, it is recommended that financial education should be intensified to educate people on financial services.
\end{abstract}

Keywords: micro-credit, former enclave-dashier chara, standard of living

\section{Introduction}

Microfinance is a form of financial development that has primarily focused on alleviating poverty through providing financial services to the poor. Most people think of microfinance, if at all, as being about micro-credit i.e. lending small amounts of money to the poor. Microfinance is not only this, but it also has a broader perspective which also includes insurance, transactional services, and importantly, savings. According to James Roth, "Microfinance is a bit of a catch all-term. Very broadly, it refers to the provision of financial products targeted at low-income groups. These financial services include credit, savings and insurance products. A series of neologisms has emerged from the provision of these services, name micro-credit, micro-savings and micro-insurance" Microfinance is the extension of small loans to entrepreneurs, who are too poor to qualify for traditional bank loans. Especially in developing countries, micro-credit enables very poor people to engage in self-employment projects that generate income, thus allowing them to improve the standard of living for themselves and their families. Poverty is a condition in which a person of community is deprived of the basic essential sand necessities for a minimum standard of living. Since poverty is understood in many senses, the essentials may be material resources such as food, safe drinking water and shelter, or they may be social resources such as access to information, education, health care, social status, political power, or the opportunity to develop meaningful connections with other people in society. According to the World Bank's (1980) definition of poverty, "A condition of life so characterized by malnutrition, illiteracy, and disease as to be beneath any reasonable definition of human decency".

It is often argued that the financial sector in low-income countries has failed to serve the poor. With respect to the formal sector, banks and other financial institutions generally require significant collateral, prefer high income and high loan clients, and have lengthy and bureaucratic application procedures. With respect to the informal sector, money-lenders usually charge excessively high interest rates, tend to undervalue collateral, and often allow racist and/or sexist attitudes to guide lending decisions. The failure of the formal and informal financial sectors to provide affordable credit to the poor is often viewed as one of the main factors that reinforce the vicious circle of economic and social 
structures that ultimately cause poverty. As a partial response to this failure, there has been significant growth in what can be termed "micro-credit" over the past two decades. Micro-credit is essentially the dispersion of small collateral-free loans to jointly liable borrowers in groups to foster income generation and poverty reduction through enhancing self-employment. Perhaps the best-known micro-credit institution is the pioneering Grameen Bank in Bangladesh. However, the Grameen model has been replicated in many countries (including high-income countries such as the Unitd States). One estimate suggests that over 10 million households worldwide are serviced by micro-credit (see Morduch, 1999). In addition, there is a view amongst key decision-makers that micro-credit has played an important role in the reduction of poverty. This optimism is reflected in the outcome of the Microcredit Summit held in 1997 where 4 policy-makers, NGOs, charitable foundations and practitioners enthusiastically pledged to reach 100 million households with micro-credit by the year 2005, at an anticipated cost of some \$20 billion (see Microcredit Summit Report, 1997). The empirical evidence on the impact of micro-credit on poverty is very mixed (see for example, Edgecomb and Barton, 1998; Morduch, 1998, 1999; Schrieder and Sharma, 1999; Sebstad and Chen, 1996; Coleman, 1999; Hossain, 1988, 1998). Some impact/evaluation studies have found that access to credit by the poor has a large positive effect on living standards. However, other studies have found that poverty is not reduced through micro-credit - poor households simply become poorer through the additional burden of debt. Since more money for micro-credit in practice means less money for other programs with similar aims, it is extremely important to carefully evaluate whether "small loans for poor people" in fact works. The purpose of this paper is to examine empirically the impact of micro-credit on poverty in Bangladesh. Unlike previous studies, the focus is on both objective and subjective poverty and particular attention is paid to the length of time programs participants have had access to micro-credit.

\section{Literature Review}

Poverty is a condition where people's basic needs for food, clothing, and shelter are not being met. "Poverty means a critical threshold of income, consumption and access to goods and services below which individuals are declared to be poor" (Roy, D, 2012).

Poverty is generally of two types:

(1) Absolute poverty occurs when people can't obtain adequate resources measured in terms of calories or nutrition to support a minimum level of physical health.

(2) Relative poverty occurs when people do not enjoy a certain minimum level of living standards as determined by a government and enjoyed by the bulk of the population. To improve poverty, livelihood pattern is also very much related to this. The word "Livelihood" is used in many ways. A livelihood refers the capabilities, assets, and activities required for a means of living. A livelihood is sustainable when it can cope with and recover from the stresses and shocks and maintain or enhance its capabilities and assets both now and in the future without undermining the natural resource base (Chambers and Conway, 1988).

The India-Bangladesh former enclaves, also known as the Chitmahals and sometime called pasha enclaves, were the enclaves along the Bangladesh-India border, in Bangladesh and the Indian states of West Bengal, Tripura, Assam and Meghalaya. Within the main body of Bangladesh were 102 enclaves of Indian Territory, which in turn contained 21 Bangladeshi counter-enclaves, one of which contained an Indian counter-counter-enclave - the world's only third-order enclave. Within the Indian mainland were 71 Bangladeshi enclaves, containing 3 Indian counter-enclaves. A joint census in 2010 found 51,549 people residing in these enclaves: 37,334 in Indian enclaves within Bangladesh and 14,215 in Bangladeshi enclaves within India. Enclaves: 37,334 in Indian enclaves within Bangladesh and 14,215 in Bangladeshi enclaves within India.

The prime ministers of India and Bangladesh signed the Land Boundary Agreement in 1974 to exchange enclaves and simplify their international border. A revised version of the agreement was adopted by the two countries on 7 May 2015, when the Parliament of India passed the 100th Amendment to the Indian Constitution. Under this agreement, which was ratified on 6 June 2015, India received 51 Bangladeshi enclaves (covering 7,110 acres (2,880 ha)) in the Indian mainland, while Bangladesh received 111 Indian enclaves (covering 17,160 acres (6,940 ha)) in the Bangladeshi mainland. The counter-enclaves, together with Dahagram-Angarpota, will not be exchanged when the Indira-Mujib agreement of 1974 is finally implemented. The enclave residents are to be allowed to either reside at their present location or move to the country of their choice. The physical exchange of enclaves will be implemented in phases between 31 July 2015 and 30 June 2016. The enclaves stand exchanged on the midnight of 31 July 2015 and the transfer of enclave residents is expected to be completed by 30 November 2015. After the Land Boundary Agreement, India lost around $40 \mathrm{~km}^{2}(10,000$ acres) to Bangladesh.

According to a popular legend, the enclaves were used as stakes in card or chess games centuries ago between two regional kings, the Raja of Koch Bihar and the Maharaja of Rangpur. As far as historical records are concerned, the little territories were apparently the result of a confused outcome of a 1713 treaty between the Kingdom of Koch Bihar and the 
Mughal Empire. Possibly, the Kingdom and the Mughals ended a war without determining a boundary for what territories had been gained or lost.

After the partition of India in 1947, Rangpur was joined to East Pakistan, and Cooch Behar district was merged in 1949 with India. The desire to "de-enclave" most of the enclaves was manifested in a 1958 agreement between Jawaharlal Nehru and Feroz Khan Noon, the respective Prime Ministers, for an exchange between India and Pakistan without considering loss or gain of territory. But the matter then worked into a Supreme Court case in India, and the Supreme Court ruled that a constitutional amendment was required to transfer the land. So, the ninth amendment was introduced to facilitate the implementation of the agreement. The amendment could not be passed because of an objection to transfer of southern Berubari enclave. Because of India's deteriorated relations with Pakistan, the issue remained unsolved. With that agreement not ratified, negotiations restarted after East Pakistan became independent as Bangladesh in 1971 following the Bangladesh Liberation War.

\section{Development of Micro-Credit in Bangladesh}

Bangladesh has experienced rapid growth in the micro-credit sector since 1990. Prior to 1990, only a handful of organizations were in operation. Many NGOs adopted and built on the experience of the Grameen Bank. Some of these NGOs experimented with the Grameen Bank micro-credit delivery system at the beginning and gradually they developed their own micro-credit delivery system (such as BRAC and ASA). Currently, more than 1,000 NGOs operate micro-credit programs in Bangladesh (see Rahman, 1999). The contribution of many of these NGOS to micro-credit disbursement is very small. For example, a study of 369 NGOs indicates that the top three NGOs as of June 1998: held 69 per cent of total credit; held 83 per cent of total net savings; held 85 per cent of cumulative credit; held 82 per cent of outstanding loans; and captured 71 per cent of the total revolving fund (see Rahman 1999). Most of the micro-credit institutions follow the flat rate method in calculating total interest. A very small number follow the declining method in calculating total interest. Under the flat rate method, NGOs charge interest rates typically between 10 to 30 per cent. The empirical analysis presented below is based on data collected for three organizations involved in micro-credit activities in Bangladesh: (1) the Grameen Bank; (2) the Bangladesh Rural Advancement Committee (BRAC); and (3) the Association of Social Advancement (ASA), (4) the Thengamara Mohila Sabuj Sangha (TMSS).

\section{Grameen Bank}

The Grameen Bank evolved from research project aimed at identifying the causes of poverty carried out by Professor Muhammad Yunus. He found that capital constraints had been forcing women to sell their handicraft products to input providers 6 at prices that were much lower than market prices. He concluded that a lack of small-scale capital in rural areas, needed for income-generating activities, was one of the main causes of poverty. This experience led him to experiment with a loan program targeted at poor people without collateral. In 1983, through a government statute, the Grameen Bank became an official financial institution. It is now regulated by the Central Bank of Bangladesh, and is the largest player in the micro-credit sector. The Grameen Bank receives funds from both the Central Bank and commercial banks (about 75 per cent of the total), along with contributions from international donors.

The Grameen Bank pioneered (and continues to employ) the "group-lending model". Five peoples with similar socio-economic status (usually from the same village), form a "group". Each member presents himself or herself as a guarantor of other members' loans. This system of "joint liability" replaces the more traditional collateral system used in the formal financial sector. If any member defaults the whole group becomes ineligible to receive additional loans. In this sense, each member of the group is responsible and liable for other members' repayment of loans. Loans are repaid in weekly installments, with each installment being equal to 2 per cent of the principal. In 2000, membership in the Grameen Bank was about 2.3 million, with a cumulative loan disbursement of about $\$ 3.2$ billion. It operates in over 40,000 villages, covering nearly half of the total land area of Bangladesh. In 2000, members had a total savings balance of $\$ 83.2$ million and the recovery rate of were near 89 per cent (see Table 1). Currently, in terms of cumulative loan disbursement the Grameen Bank is the largest micro-credit organization in Bangladesh.

After independence in 1971, the Bangladesh Rural Advancement Committee (BRAC) was established. Initially its main objective was to conduct relief and 7 rehabilitation programs. It continued to widen its activities and in 1976 established a micro-credit program. At present it is prominent among the biggest NGOs in terms of development and micro-credit activities. BRAC started its micro-credit program in 1976. Its current program was initiated in 1990 and is known as the "Rural Credit Project". BRAC's other development activities include free informal education and health and medical facilities to low-income people in rural areas. In 2002, membership in BRAC was about 3.9 million, with a total loan disbursement of about $\$ 1$ billion. In 2000 the cumulative savings of BRAC stood at $\$ 65$ million. In the same year it aChieved a recovery rate of $98.4 \%$. Currently, BRAC is the second largest micro-credit organization in Bangladesh. The Association of Social Advancement (ASA) was established in 1978. It began its micro-credit programme in 1991. Currently, ASA is the third largest micro-credit organization in Bangladesh. It has developed a less expensive model for the implementation of savings and credit program, which has helped it become a more cost effective and sustainable 
program (Jain, 1999; Rutherford, 1995). Kalily, Imam and Khan (2000) conclude that ASA is more cost effective and more sustainable than the Grameen Bank. By 2000, ASA had extended credit to poor people in 22,740 villages out of approximately 86,000 villages in Bangladesh. The total number of members of ASA in 2000 was 1.2 million. In the same year the cumulative loan disbursement and cumulative savings of members stood at \$466 million and \$97 million respectively. In 2000 the recovery rate of ASA was $99.9 \%$.

\section{BRAC}

BRAC was initiated in 1972 by Sir Fazlé Hasan Abed at Shallah Upazilla in the district of Sunamganj as a small-scale relief and rehabilitation project to help returning war refugees after the Bangladesh Liberation War of 1971. In nine months, 14 thousand homes were rebuilt as part of the relief effort and several hundred boats were built for the fishermen. Medical centers were opened and other essential services were ensured. At the end of 1972, when the first phase of relief work was over, BRAC turned towards long-term development needs and re-organized itself to focus on the empowerment of the poor and landless, particularly women and Children. BRAC employs over 100,000 people, roughly 70 Percentage of who are women, reaChing more than 126 million people. The organization is $70-80 \%$ self-funded through a number of commercial enterprises that include a dairy and food project and a chain of retail handicraft stores called Aarong. BRAC maintains offices in 14 countries throughout the world, including BRAC USA and BRAC UK.

\section{ASA}

In 1971, Bangladesh emerged as an independent nation through a bloody war and at a cost of millions of lives. The country was left behind in a state ravaged by the war and natural disaster, but populated by a significant number of young people full of hope, energy and commitment for reconstruction and nation-building. The economy of Bangladesh is largely dependent on agriculture and still a major segment of population lives in rural areas. During the post-war era, this economy suffered a huge blow due to the political upheaval and poor control mechanism. Main constraints were frequent agitations, political unrest and numerous changes of governments that were too inexperienced to uphold stability and discipline. In such chaotic circumstances, policy formulation or planning for development was difficult. The situation even got worsen when a famine broke-out in 1974. The economic growth was hindered, and unemployment rate soared. Measures taken by the government were appallingly insufficient. As the new government failed to meet the challenges, even with overseas assistance, small non-government organizations emerged over the 1970s to provide relief and rehabilitation along with community development. The administrative structure, that followed a top-down approach for development, could not cope with the actual socio-economic reality as the institutional structures failed to reach the downtrodden people. In those volatile days ASA was born in 1978 at a remote village Tapra, under the then Manikganj sub-division about 80 kilometers away from the capital Dhaka.

\section{TMSS}

Thengamara Mohila Sabuj Sangha (TMSS) is a micro credit NGO from Bangladesh. TMSS, founded by Professor Dr. Hosne Ara Begum, Ashoka Fellow, in 1980 in Bogra, Bangladesh, is a women-oriented Bangladeshi organization working for alleviation of poverty, empowerment of women and improvement of socio-economic infrastructure of Bangladesh. TMSS has partnered with many organizations, including NCC Bank Limited to help enhance services available in more rural areas.

\section{Objectives of the Study}

In the light of this research topic, the objectives of this study are on the following:

1. To explore how micro credit activities affect the living standard (income, housing condition, sanitation, health and education etc.) of rural people.

2. To examine reasons to relate with micro-credit organizations.

\section{Methodology}

To fulfill the aims and objectives of the study, an empirical approach has been chosen. The approach with set questionnaire has been prepared to collect data from respondents. Random sampling methods were used to select the respondents for the study. We did Univariate Analysis of the characteristics of the respondents and their families. To analyze the impact, we applied multiple regression analysis.

\section{Statement of the Problem}

It has been recognized that through micro credit activities the poor people can improve their living standard. Mainly these micro finance institutions give loan who are poor and trying to reduce poverty as well as to improve their living standard. In these cases, microfinance organizations help them to spread out their business by offering them different kinds of small loans, which is a common feature of microfinance institutions. 


\subsection{Hypothesis}

In this paper, micro-credit activities of all micro-credit institutions and their impact is positive to improve the living standards of poor people.

\subsection{Preparing Research Design Including Sample Design}

To determine the sample size from Dasiar Chara, the following formulas was applied:

$$
n=\frac{N^{*} Z^{2} * P *(P-1)}{N^{*} d^{2}+Z^{2} * P *(P-1)}
$$

Where, $\mathrm{n}=$ Sample size; $\mathrm{N}=$ population; $\mathrm{d}=$ Sampling error; $\mathrm{P}=$ the largest possible proportion and $\mathrm{Z}=$ the value of the normal variable (1.96) for a reliability level of .95

In the study,

Population size $=450$ families

For this study, the reliability level $\mathrm{z}=1.96$

The allowed sampling error, $\mathrm{d}=0.05$ and

The largest possible proportion for the study, $\mathrm{P}=0.50$

Thus, the required sample size is

$$
\begin{gathered}
n=\frac{450 \times(1.96)^{2} \times 0.05 \times(1-0.05)}{450(1.96)^{2}+(1.96) 2 \times 0.05 \times(1-0.05)} \\
\approx 150
\end{gathered}
$$

Therefore, the required sample size is 150 families.

\section{Collecting the Data and Executing the Data}

To conduct the research, we used the primary source of data for which we had to use the questionnaire method. We collected data from 150 respondents.

\section{Univariate Analysis of the Characteristics of the Respondents and their Families}

We had tried to construct univariate frequency distribution of several factors, different variables, like Family Units, Age of Respondent, Gender of Respondent, Profession of Respondent, Religion of Respondent, Smoking Behavior, Family Size, Highest Education Level For Male Members and Male Members, Meals Per Day Taken By Each Family, Family is Joint or Not, Present Home Type of Respondents, Number of Homes of the Respondents, Telecommunication condition before joining Micro-credit organizations, Present Sanitation of Respondents, Present Primary Faith for Treatment of Respondents, Income of Respondent Family (Tk. per month), Savings of Respondents' Family(Tk. per month), Total Land of Respondents' Family( in Acre ), Cultivable land of Respondents' Family( in Acre ), Relation with Micro-credit of Respondents' Family, Duration of Relationship with Micro Credit Organizations, Numbers of Micro-Credit Organizations Relate with Respondent Family, Name of Micro-Credit Organizations Relate with Respondents' Family, Expected Loan by Respondents From Micro-Credit Organizations (Tk. per year), Amount of Loan Taken by Respondents From Micro-Credit Organizations (Tk. per year), Amount of Payment Taken as Loan by Respondents From Micro-Credit Organizations (Tk. per year), Essentiality of taking these loans, Objectives of Taking These loans, Success AChieved After Taking Loan, Condition of Homes Before Joining Micro-Credit Organizations, Primary Faith of Treatment of Respondents Before Joining Micro-Credit Organizations, Sanitation Condition Before Joining Micro-Credit Organizations, Usages of Mobile Phone Before and After Joining Micro-Credit Organizations, Improvement on Property, Improvement on Educational Status, Improvement on Health Condition, Improvement on Housing Condition, and so on related to the study.

\subsection{Frequency Distribution by Age of Respondents}

By using SPSS, we get the following frequency table for age:

\begin{tabular}{cccc} 
Age Range & Frequency & Percentage & Cumulative Percentage \\
\hline $20-35$ & 35 & 23.3 & 23.3 \\
$35-50$ & 64 & 42.7 & 66.0 \\
$50-65$ & 38 & 25.3 & 91.3 \\
$65-80$ & 10 & 6.7 & 98.0 \\
$80-95$ & 3 & 2.0 & 100.0 \\
Total & 150 & 100.0 & \\
\hline
\end{tabular}

Interpretation: From the table, we see that most of the respondents belonged to age interval 35-50 and the lowest from 
age interval of 80-85.

8.2 Frequency Distribution by Gender of Respondents

By using SPSS, we get the following frequency table for Gender:

\begin{tabular}{cccc}
\hline Gender & Frequenc & Percentage & Cumulative Percentage \\
\hline Female & 20 & 13.3 & 13.3 \\
Male & 130 & 86.7 & 100.0 \\
Total & 150 & 100.0 & \\
\hline
\end{tabular}

Interpretation: From the table we see that about $13.33 \%$ of the respondents were female and about $86.67 \%$ of the respondents were male. Thus, in our study, most of the respondents were male.

8.3 Frequency Distribution by Profession of Respondents

By using SPSS, we get the following frequency table for Profession:

\begin{tabular}{cccc}
\hline Category & Frequency & Percentage & Cumulative Percentage \\
\hline Farmer & 67 & 44.7 & 44.7 \\
Labor & 38 & 25.3 & 70.0 \\
Businessman & 20 & 13.3 & 83.3 \\
Teacher & 6 & 4.0 & 87.3 \\
Tailor & 2 & 1.3 & 88.7 \\
Housewife & 13 & 8.7 & 97.3 \\
Employee & 4 & 2.7 & 100.0 \\
Total & 150 & 100.0 & 100.0 \\
\hline
\end{tabular}

Interpretation: From the table we see that mainly seven categories for profession are present in our study. About $44.67 \%$ of the respondents were farmers and approximately $1.33 \%$ of the respondents were Tailors. Most of the respondents, therefore, were farmers.

8.4 Frequency Distribution by Family Size of Respondents

By using SPSS, we get the following frequency table for family size:

\begin{tabular}{cccc}
\hline Family Size & Frequency & Percentage & Cumulative Percentage \\
\hline 2 & 1 & 0.7 & 0.7 \\
3 & 22 & 14.7 & 15.3 \\
4 & 38 & 25.3 & 40.7 \\
5 & 34 & 22.7 & 63.3 \\
6 & 27 & 18.0 & 81.3 \\
7 & 21 & 14.0 & 95.3 \\
8 & 4 & 2.7 & 98.0 \\
9 & 1 & 0.7 & 98.7 \\
10 & 1 & 0.7 & 99.3 \\
11 & 1 & 0.7 & 100.0 \\
Total & 150 & 100.0 & 100.0 \\
\hline
\end{tabular}

Interpretation: From the table we see that almost $22.67 \%$ of the respondents had 5 members in the family and $63.3 \%$ of the respondents had 5 or less than 5 members. About $95 \%$ of the respondents had 7 or less than 7 members in the family. In contrast, most of the respondents had 5 to 7 members.

\subsection{Frequency Distribution by Family Types of Respondents}

By using SPSS, we get the following frequency table for family type:

\begin{tabular}{cccc}
\hline Category & Frequency & Percentage & Cumulative Percentage \\
\hline Single family & 54 & 36.0 & 36.0 \\
Joint Family & 96 & 64.0 & 100.0 \\
Total & 150 & 100.0 & \\
\hline
\end{tabular}

Interpretation: From the table we see that, about $64 \%$ of the respondents belonged to single family and about $36 \%$ of the respondents were from joint family.

\subsection{Frequency Distribution by Income and Saving of Respondents}

By using SPSS, we get the following frequency table for Income and Savings:

\begin{tabular}{cccc}
\hline Saving Interval (Tk. per month) & Frequency & Percentage & Cumulative Percentag \\
\hline $0-100$ & 43 & 28.7 & 28.7 \\
$100-500$ & 49 & 32.7 & 61.3 \\
$500-1000$ & 25 & 16.7 & 78.0 \\
$1000-5000$ & 30 & 20.0 & 98.0 \\
$5000-20000$ & 3 & 2.0 & 100.0 \\
Total & 150 & 100.0 & \\
\hline
\end{tabular}




\begin{tabular}{cccc}
\hline Income Interval (Tk. per month) & Frequency & Percentage & Cumulative Percentage \\
\hline $2000-3000$ & 59 & 39.3 & 39.3 \\
$3000-5000$ & 47 & 31.3 & 70.7 \\
$5000-7000$ & 12 & 8.0 & 78.7 \\
$7000-10000$ & 12 & 8.0 & 86.7 \\
$10000-100000$ & 20 & 13.3 & 100.0 \\
Total & 150 & 100.0 & \\
\hline
\end{tabular}

Interpretation: From the above table we see that, most of the respondent income were from earning 2000 to $5000 \mathrm{Tk}$. per month. That means, most of families were poor.

\subsection{Frequency Distribution by Land (Total and Cultivation) of Respondents}

By using SPSS, we get the following frequency table for land (cultivation and total):

Total Land of the Respondents (in Acre)

\begin{tabular}{cccc}
\hline Range & Frequency & Percentage & Cumulative Percentage \\
\hline $0-10$ & 34 & 22.7 & 22.7 \\
$10-50$ & 37 & 24.7 & 47.3 \\
$50-100$ & 30 & 20.0 & 67.3 \\
$100-200$ & 28 & 18.7 & 86.0 \\
$200-2500$ & 21 & 14.0 & 100.0 \\
Total & 150 & 100.0 \\
\hline \multicolumn{4}{c}{ Cultivable Land of the Respondents (in Acre) } \\
\hline Range & Frequency & Percentage & Cumulative Percentage \\
\hline $0-10$ & 55 & 36.7 & 36.7 \\
$10-50$ & 33 & 22.0 & 58.7 \\
$50-100$ & 27 & 18.0 & 76.7 \\
$100-200$ & 22 & 14.7 & 91.3 \\
$200-2500$ & 13 & 8.7 & 100.0 \\
Total & 150 & 100.0 & \\
\hline
\end{tabular}

Interpretation: From the above table we see that about $22 \%$ of the respondents were landless and most of the respondent families had less than 200 Acre lands.

\subsection{Frequency Distribution by Relation with Micro-Credit of Respondents}

By using SPSS, we get the following frequency table for finding the relation with micro-credit of respondents:

\begin{tabular}{cccc}
\hline Category & Frequency & Percentage & Cumulative Percentage \\
\hline Yes & 74 & 49.3 & 49.3 \\
No & 76 & 50.7 & 100.0 \\
Total & 150 & 100.0 &
\end{tabular}

Interpretation: From the above table we see that about half of the families was related with micro-credit and the rest was not.

\subsection{Frequency Distribution by Duration of Relation with Micro Credit Organization of Respondents}

By using SPSS, we get the following frequency table for duration of relation with Micro-Credit organizations:

\begin{tabular}{cccc}
\hline Category & Frequency & Percentage & Cumulative Percentage \\
\hline$<$ 1 year & 19 & 25.7 & 25.7 \\
1-2 year & 35 & 47.3 & 73.0 \\
2-3 year & 14 & 18.9 & 91.9 \\
3-4 year & 6 & 8.1 & 100.0 \\
Total & 74 & 100.0 & \\
\hline
\end{tabular}

Interpretation: From the above table we see that about half of the respondent families related with micro-credit were new and most of the respondents' families were engaged in any organizations for two or less than two years.

\subsection{Frequency Distribution by Numbers of Organizations Related to Families of Respondents}

By using SPSS, we get the following frequency table for family size:

\begin{tabular}{cccc}
\hline Category & Frequency & Percentage & Cumulative Percentage \\
\hline 1 & 60 & 81.1 & 81.1 \\
2 & 11 & 14.9 & 95.9 \\
3 & 3 & 4.1 & 100.0 \\
Total & 74 & 100.0 & \\
\hline
\end{tabular}


Interpretation: From the above table we see that most of the respondent families were related to only one organization.

8.11 Frequency Distribution by Number of Organizations' Relation with Families of Respondents

By using SPSS, we get the frequency table for family size:

\begin{tabular}{cccc}
\hline Name of the micro- credit institution & Frequency & Percentage & Cumulative Percentage \\
\hline G.B & 30 & 40.5 & 40.5 \\
TMSS & 12 & 16.2 & 56.8 \\
ASA & 13 & 17.6 & 74.3 \\
Zubo Unnoyon & 5 & 6.8 & 81.1 \\
GB \& TMSS & 2 & 2.7 & 83.8 \\
GB \& ASA & 8 & 10.8 & 94.6 \\
TMSS \& ASA & 1 & 1.4 & 95.9 \\
GB, TMSS \& ASA & 3 & 4.1 & 100.0 \\
Total & 74 & 100.0 & \\
\hline
\end{tabular}

Interpretation: From the above table we see that, about $41 \%$ respondents were linked with Grameen Bank compared to other micro finance institutions. So, we can say that Grameen Bank provides more than the others organizations.

8.12 Frequency Distribution by the Amount of Loan Taken by Each Family

By using SPSS, we get the following frequency table for the amount of loan taken by each family:

\begin{tabular}{cccc}
\hline Range & Frequency & Percentage & Cumulative Percentage \\
\hline $2000-5000$ & 8 & 10.8 & 10.8 \\
$5000-8000$ & 27 & 36.5 & 47.3 \\
$8000-15000$ & 14 & 18.9 & 66.2 \\
$15000-20000$ & 8 & 10.8 & 77.0 \\
$20000-30000$ & 9 & 12.2 & 89.2 \\
$30000-60000$ & 6 & 8.1 & 97.3 \\
$60000-200000$ & 2 & 2.7 & 100.0 \\
Total & 74 & 100.0 & \\
\hline
\end{tabular}

Interpretation: From the above table we see that most of the families had taken loan from 5000-8000 Tk.

8.13 Frequency Distribution of Objectives of Respondents to Take Loans

By using SPSS, we get the frequency table for the objectives of respondents:

\begin{tabular}{cccc}
\hline Category & Frequency & Percentage & Cumulative Percentage \\
\hline Business & 29 & 39.2 & 39.2 \\
Food & 29 & 39.2 & 78.4 \\
Agriculture & 14 & 18.9 & 97.3 \\
Daughter Marriage & 1 & 1.4 & 98.6 \\
Treatment & 1 & 1.4 & 100.0 \\
Total & 74 & 100.0 & \\
\hline
\end{tabular}

Interpretation: About 39\% of families had taken loans for business purpose and another 39\% for selling food and around $19 \%$ had taken for agriculture.

\subsection{Frequency Distribution by Essentiality for Taking Loans}

By using SPSS, we get the frequency table for essentiality of taking loan:

\begin{tabular}{cccc}
\hline Criteria & Frequency & Percentage & Cumulative Percentage \\
\hline Extreme & 40 & 54.1 & 54.1 \\
Medium & 24 & 32.4 & 86.5 \\
Low & 10 & 13.5 & 100.0 \\
Total & 74 & 100.0 & \\
\hline
\end{tabular}

Interpretation: From the above data we see that about 55\% of families had taken for extreme needs and about $33 \%$ had taken for medium needs.

\subsection{Frequency Distribution of the Condition of Homes of Respondents before and after Joining with Micro-Credit}

By using SPSS, we get the following frequency table for the home types of respondents before and after joining with micro-credit, which are given below: 
Before taking loan

\begin{tabular}{cccc}
\hline Category & Frequency & Percentage & Cumulative Percentage \\
\hline Bamboo & 15 & 20.3 & 20.3 \\
Bamboo and tin & 47 & 63.5 & 83.8 \\
Soil & 6 & 8.1 & 91.9 \\
Bricks & 6 & 8.1 & 100.0 \\
Total & 74 & 100.0 & \\
\hline \multicolumn{4}{c}{ After taking loan } \\
\hline Category & Frequency & Percentage & Cumulative Percentage \\
\hline Bamboo & 7 & 9.5 & 9.5 \\
Bamboo and tin & 53 & 71.6 & 81.1 \\
Soil & 6 & 8.1 & 100.0 \\
Bricks & 8 & 10.8 & \\
Total & 74 & 100.0 &
\end{tabular}

Interpretation: From the above table we see that, there is positive change of home conditions after taking loans from micro-credit organizations.

8.16 Frequency Distribution of the Sanitation Types of Respondents before and after Joining Micro-Credit

By using SPSS, we get the following frequency table for the sanitation types of respondents

Before

\begin{tabular}{cccc}
\hline Category & Frequency & Percentage & Cumulative Percentage \\
\hline No Sanitary latrine & 21 & 28.4 & 28.4 \\
Having sanitary latrine & 53 & 71.6 & 100.0 \\
Total & 74 & 100.0 & \\
\hline \multicolumn{4}{c}{ After } \\
\hline Category & Frequency & Percentage & Cumulative Percentage \\
\hline No Sanitary Latrine & 10 & 13.5 & 13.5 \\
Having sanitary latrine & 64 & 86.5 & 100.0 \\
Total & 74 & 100.0 & \\
\hline
\end{tabular}

Interpretation: From the above tables we see that, there is positive change in sanitation condition after taking loans from micro-credit organizations.

\subsection{Frequency Distribution of the Treatment Process of Respondents before and after Joining Micro-Credit}

By using SPSS, we get the following frequency table for the treatment process of respondents before and after joining micro-credit program, which are given below:

\begin{tabular}{cccc}
\multicolumn{5}{c}{ Before } \\
\hline Category & Frequency & Percentage & Cumulative Percentage \\
\hline Quack & 6 & 8.1 & 8.1 \\
Village Doctors & 68 & 91.9 & 100.0 \\
Total & 74 & 100.0 & \\
\hline \multicolumn{4}{c}{ After } \\
\hline Category & Frequency & Percentage & Cumulative Percentage \\
\hline Quack & 4 & 5.4 & 5.4 \\
Village Doctors & 69 & 93.2 & 98.6 \\
MBBS & 1 & 1.4 & 100.0 \\
Total & 74 & 100.0 &
\end{tabular}

Interpretation: From the above tables we see that, there is positive change of the treatment process of respondent after taking loans from micro-credit organizations.

8.18 Frequency Distribution of the Mobile Operator Types of Respondents before and after Joining Micro-Credit

By using SPSS, we get the following frequency table for the Telecommunication condition before and after joining Micro-credit organizations, which are given below: 
Telecommunication condition before joining Micro-credit organizations

\begin{tabular}{cccc}
\hline Category & Frequency & Percentage & Cumulative Percentage \\
\hline No operator & 21 & 28.4 & 28.4 \\
GP & 49 & 66.2 & 94.6 \\
BL & 1 & 1.4 & 95.9 \\
GP, BL & 2 & 2.7 & 98.6 \\
GP, BL, ROBI & 1 & 1.4 & 100.0 \\
Total & 74 & 100.0 & \\
\hline
\end{tabular}

\begin{tabular}{cccc}
\hline \multicolumn{4}{c}{ Telecommunication condition after joining Micro-credit organizations } \\
\hline Category & Frequency & Percentage & Cumulative Percentage \\
\hline No operator & 5 & 6.8 & 6.8 \\
GP & 62 & 83.8 & 90.5 \\
BL & 2 & 2.7 & 93.2 \\
GP, BL & 4 & 5.4 & 98.6 \\
GP, BL, ROBI & 1 & 1.4 & 100.0 \\
Total & 74 & 100.0 & \\
\hline
\end{tabular}

Interpretation: From the above table we see that, there is positive change in using mobile operators after taking loans from micro-credit organizations.

8.19 Frequency Distribution of the Opinion of the Respondents about the Improvements on Home Types after Joining Micro-Credit

By using SPSS, we get the following frequency table for the opinion of the respondents about the improvements on home types of respondents after joining micro-credit program:

\begin{tabular}{cccc}
\hline Category & Frequency & Percentage & Cumulative Percentage \\
\hline No & 10 & 13.5 & 13.5 \\
Yes & 64 & 86.5 & 100.0 \\
Total & 74 & 100.0 & \\
\hline
\end{tabular}

Interpretations: From the above table we see that about $87 \%$ of the respondents had improvements by taking loans on changing home conditions.

8.20 Frequency Distribution of the Opinion of the Respondents about the Improvements on Health Conditions after Joining Micro-Credit

By using SPSS, we get the following frequency table for the opinion of the respondents about the improvements on health conditions of respondents after joining micro-credit program.

Improvement on health condition

\begin{tabular}{cccc}
\hline Category & Frequency & Percentage & Cumulative Percentage \\
\hline No & 18 & 24.3 & 24.3 \\
Yes & 56 & 75.7 & 100.0 \\
Total & 74 & 100.0 & \\
\hline
\end{tabular}

Interpretation: From the above table we see that about $76 \%$ of the respondents had seen improvements by taking loans on improvements on health conditions.

8.21 Frequency Distribution of the Opinion of the Respondents about the Improvements on Education after Joining Micro-Credit

By using SPSS, we get the following frequency table for the opinion of the respondents about the improvements on education of respondents after joining micro-credit program:

Improvement on educational status

\begin{tabular}{cccc}
\hline Category & Frequency & Percentage & Cumulative Percentage \\
\hline No & 14 & 18.9 & 18.9 \\
Yes & 60 & 81.1 & 100.0 \\
Total & 74 & 100.0 & \\
\hline
\end{tabular}

Interpretation: From the above table we see that about $87 \%$ of the respondents had seen improvements on education by taking loans on changing home conditions.

8.22 Frequency Distribution of the Opinion of the Respondents about the Improvements on Properties after Joining Micro-Credit

By using SPSS, we get the following frequency table for the opinion of the respondents about the improvements on 
properties of respondents after joining micro-credit program.

Improvement on property

\begin{tabular}{lccc}
\hline Category & Frequency & Percentage & Cumulative Percentage \\
\hline No & 15 & 20.3 & 20.3 \\
Yes & 59 & 79.7 & 100.0 \\
Total & 74 & 100.0 & \\
\hline
\end{tabular}

Interpretation: From the above table we see that about $80 \%$ of the respondents had not seen improvements on properties by taking loans.

\section{Contingency Analysis}

We represent contingency analysis, which is designed to test any association between different phenomenon, contingency analysis, if ' $\mathrm{O}$ ' denoted Observed frequency and ' $\mathrm{E}$ ' denote Expected frequency of a contingency table, then the Expected frequency under any hypothesis is

$E_{i j}=\frac{R_{i} \times C_{j}}{N}$

Where,

$\mathrm{E}_{\mathrm{ij}}=$ Expected frequency of $\mathrm{i}^{\text {th }}$ row and $\mathrm{j}^{\text {th }}$ columns.

$\mathrm{R}_{\mathrm{i}}=$ Number of observation at the $\mathrm{i}^{\text {th }}$ row in the respective contingency table.

$\mathrm{C}_{\mathrm{j}}=$ Number of data at the $\mathrm{j}^{\mathrm{th}}$ column of the respective contingency table.

$\mathrm{N}=$ Total number of observation.

From each contingency table examination of the association between the components and the different segment of the component are made by computing Chi-square and using the formula is given by:

$$
\chi^{2}=\sum_{\mathrm{i}} \sum_{\mathrm{j}} \frac{\mathrm{o}_{\mathrm{ij}}^{2}}{\mathrm{E}_{\mathrm{ij}}}-\mathrm{N} \sim \chi_{(\mathrm{r}-1)(\mathrm{c}-1)}^{2}
$$

Where, $\quad \mathrm{o}_{\mathrm{ij}}^{2}=$ The Observed number of data in $(i, j)^{t h}$ cell

$\mathrm{E}_{\mathrm{ij}}=$ the Exp. number of data in $(i, j)^{\text {th }}$ Cell

Finally comparing the calculated value of $\chi^{2}$ and tabulated value of $\chi^{2}$ and we present the Interpretations.

\subsection{The Distribution of Respondents by Relation with Micro-Credit and Age of the Respondents}

In our study we get the distribution relation with micro-credit and age of the respondents by using SPSS:

Table 1. Distribution of respondents by relation with micro-credit and age of the respondents:

Relation with micro-credit of respondent family * Age interval of the respondent cross tabulation

\begin{tabular}{cccccccc}
\hline \multirow{2}{*}{ Category } & \multicolumn{7}{c}{ Age interval of the Respondent } \\
& $20-35$ & $35-50$ & $50-65$ & $65-80$ & $80-95$ & Total \\
\cline { 2 - 7 } Yes & 16 & 37 & 18 & 3 & 0 & 74 \\
No & 19 & 27 & 20 & 7 & 3 & 76 \\
Total & 35 & 64 & 38 & 10 & 3 & 150 \\
\hline
\end{tabular}

We want to test the hypothesis

$H_{0}$ : There is no impact on relation with micro-credit and the age of the respondents

$H_{1}: H_{0}$ is not true.

\section{Chi-Square Tests}

\begin{tabular}{cccc}
\hline & Value & df & Asymp. Sig. (2-sided) \\
\hline Pearson Chi-Square & 6.499 & 4 & .165 \\
Likelihood Ratio & 7.710 & 4 & .103 \\
Linear-by-Linear Association & 1.809 & 1 & .179 \\
No of Valid Cases & 150 & & \\
\hline
\end{tabular}

Interpretation: From above table we see that at 5\% level of significance Chi-Square is greater than 0.05. So, the null hypothesis is not rejected and there is no impact on relation with micro-credit and age of the respondents 


\subsection{The Distribution of Respondents by Relation with Micro-Credit and Gender of the Respondents}

In our study we get the distribution Relation with Micro-credit and gender of the respondents by using SPSS.

Table 2. Distribution of respondents by Relation with Micro-credit and gender of the respondents:

Relation with micro-credit of respondent family \& gender of respondent cross tabulation

\begin{tabular}{ccccc}
\hline & & \multicolumn{3}{c}{ Gender of Respondent } \\
& & Female & Male & Total \\
\hline Relation with micro-credit of & yes & 16 & 58 & 74 \\
respondent family & no & 4 & 72 & 76 \\
& Total & 20 & 130 & 150 \\
\hline
\end{tabular}

We want to test the hypothesis

$H_{0}$ : There is no impact on relation with micro-credit and gender of the respondents

$H_{1}: H_{0}$ is not true.

\section{Chi-Square Test}

\begin{tabular}{cccccc}
\hline & Value & df & Asymp. Sig. (2-sided) & Exact Sig. (2-sided) & Exact Sig. (1-sided) \\
\hline Pearson Chi-Square & 8.683 & 1 & .003 & & \\
Continuity Correction & 7.325 & 1 & .007 & & \\
Likelihood Ratio & 9.194 & 1 & .002 & .004 & .003 \\
Fisher's Exact Test & & & & & \\
Linear-by-Linear Association & 8.625 & 1 & .003 & & \\
No of Valid Cases & 150 & & & & \\
\hline
\end{tabular}

Interpretation: From above table we see that at 5\% level of significance Chi-Square is less than 0.05. So, the null hypothesis is not rejected. That is, there is an impact on relationship with micro-credit and gender of the respondents.

\subsection{The Distribution of Respondents by Relation with Micro-Credit and Profession of the Respondents}

In our study we get the frequency distribution of relationship with Micro-credit and Profession of the Respondents by using SPSS.

Table 3. Distribution of respondents by relation with micro-credit and profession of the respondents:

Relation with micro-credit of respondent family \& profession of respondent cross tabulation

\begin{tabular}{cccccccccc}
\hline & & \multicolumn{7}{c}{ Profession of respondent } \\
\hline & & Farmer & Labor & Businessman & Teacher & Tailor & Housewife & Employee & Total \\
elation with & Yes & 24 & 22 & 12 & 4 & 2 & 10 & 0 & 74 \\
Micro-Credit of & No & 43 & 16 & 8 & 2 & 0 & 3 & 4 & 76 \\
$\begin{array}{c}\text { Respondent Family } \\
\text { Total }\end{array}$ & & 67 & 38 & 20 & 6 & 2 & 13 & 4 & 150 \\
\hline
\end{tabular}

We want to test the hypothesis

$H_{0}$ : There is no impact on relation with micro-credit and profession of the respondents vs $H_{1}: H_{0}$ is not true.

\begin{tabular}{cccc}
\multicolumn{4}{c}{ Chi-Square Test } \\
\hline & Value & df & Asymp. Sig. (2-sided) \\
\hline Pearson Chi-Square & 17.548 & 6 & .007 \\
Likelihood Ratio & 20.167 & 6 & .003 \\
Linear-by-Linear Association & 4.043 & 1 & .044 \\
Number of Valid Cases & 150 & & \\
\hline
\end{tabular}

Interpretation: From above table we see that at 5\% level of significance Chi-Square is less than 0.05 . So, the null hypothesis is accepted. That is, there is an impact on relation with micro-credit and profession of the respondents.

\subsection{The Distribution of Respondents by Relation with Micro-Credit and Religion of the Respondents}

In our study we get the distribution Relation with Micro-credit and Religion of the Respondents by using SPSS.

Table 4. Distribution of respondents by Relation with Micro-credit and Religion of the Respondents: 
Relation with Micro-Credit of Respondent Family * Religion of Respondent Cross tabulation

\begin{tabular}{ccccc}
\hline & & \multicolumn{2}{c}{ Religion of Respondent } & \multirow{2}{*}{ Total } \\
Count & & Muslim & Hindu & \multirow{2}{*}{} \\
\hline Relation with Micro-Credit of & yes & 50 & 24 & 74 \\
Respondent Family & no & 72 & 4 & 76 \\
Total & & 122 & 28 & 150 \\
\hline
\end{tabular}

We want to test the hypothesis

$H_{0}$ : There is no impact on relation with micro-credit and religion of the respondents

$H_{1}: H_{0}$ is not true.

Chi-Square Tests

\begin{tabular}{cccccc}
\hline & Value & df & Asymp. Sig. (2-sided) & Exact Sig. (2-sided) & Exact Sig. (1-sided) \\
\hline Pearson Chi-Square & 18.230 & 1 & .000 & & \\
Continuity Correction & 16.484 & 1 & .000 & .000 & .000 \\
Likelihood Ratio & 19.812 & 1 & .000 & & \\
$\begin{array}{c}\text { Fisher's Exact Test } \\
\text { Linear-by-Linear } \\
\text { Association }\end{array}$ & 18.108 & 1 & .000 & & \\
N of Valid Cases & 150 & & & & \\
\hline
\end{tabular}

Interpretation: From above table we see that at 5\% level of significance Chi-Square is less than 0.05. So, the null hypothesis is accepted. That is, there is an impact on relation with micro-credit and religion of the respondents

9.5 The Distribution of Respondents by Relation with Micro-Credit and Income (Monthly in Tk.) of the Respondents' Family

In our study we get the distribution Relation with Micro-credit and Income (monthly in Tk.) of the respondent family by using SPSS:

Table 5. Distribution of Respondents by Relation with Micro-credit and Income (monthly in Tk.) of the Respondents Family

Relation with Micro-Credit of Respondent Family * Income Interval of the Respondent (Tk. per month) Cross tabulation

\begin{tabular}{cccccccc}
\hline & \multicolumn{7}{c}{ Income Interval of the Respondents (Tk. per month) } \\
Count & & $2000-3$ & $3000-5$ & $5000-7$ & $7000-100$ & $10000-100$ & Total \\
& & 000 & 000 & 000 & 00 & 000 & \\
Relation with Micro-Credit & Yes & 33 & 21 & 5 & 5 & 10 & 74 \\
of Respondent Family & No & 26 & 26 & 7 & 7 & 10 & 76 \\
Total & & 59 & 47 & 12 & 12 & 20 & 150 \\
\hline
\end{tabular}

We want to test the hypothesis

$H_{0}$ : There is no impact on relation with micro-credit and income (monthly in Tk.) of the respondent family.

Vs $H_{1}: H_{0}$ is not true.

Chi-Square Tests

\begin{tabular}{cccc}
\hline & Value & df & Asymp. Sig. (2-sided) \\
\hline Pearson Chi-Square & 2.003 & 4 & .735 \\
Likelihood Ratio & 2.009 & 4 & .734 \\
Linear-by-Linear Association & .536 & 1 & .464 \\
N of Valid Cases & 150 & & \\
\hline
\end{tabular}

Interpretation: From above table we see that at $5 \%$ level of significance Chi-Square is greater than 0.05 . So, the null hypothesis is not accepted. That is, there is no impact on relation with micro-credit and income (monthly in Tk.) of the respondent family

9.6 The Distribution of Respondents by Relation with Micro-Credit and Saving (Monthly in Tk.) of the Respondents Family

In our study we get the distribution Relation with Micro-credit and saving (monthly in Tk.) of the respondent family by using SPSS: 
Table 6. Distribution of respondents by Relation with Micro-credit and savings (monthly in Tk.) of the Respondents Family:

Relation with Micro-Credit of Respondent Family * Saving Interval of the Respondent (Tk. per month) Cross tabulation

\begin{tabular}{|c|c|c|c|c|c|c|}
\hline & & \multicolumn{4}{|c|}{ Saving Interval of the Respondent (Tk. per month) } & Total \\
\hline Count & & $100-500$ & $500-1000$ & $1000-5000$ & $5000-20000$ & \\
\hline Relation with Micro-Credit & Yes & 26 & 11 & 13 & 2 & 74 \\
\hline of Respondent Family & No & 23 & 14 & 17 & 1 & 76 \\
\hline Total & & 43 & 25 & 30 & 3 & 150 \\
\hline
\end{tabular}

We want to test the hypothesis

$H_{0}$ : There is no impact on relation with micro-credit and saving of the respondent family

$H_{1}: H_{0}$ is not true.

Chi-Square Tests

\begin{tabular}{cccc}
\hline & Value & df & Asymp. Sig. (2-sided) \\
\hline Pearson Chi-Square & $1.407 \mathrm{a}$ & 4 & .843 \\
Likelihood Ratio & 1.416 & 4 & .841 \\
Linear-by-Linear Association & .348 & 1 & .555 \\
No of Valid Cases & 150 & &
\end{tabular}

Interpretation: From above table we see that at 5\% level of significance Chi-Square is greater than 0.05. So, the null hypothesis is not accepted. That is, there is no impact on relation with micro-credit and saving (monthly in Tk.) of the respondent family.

9.7 The Distribution of Respondents by Present Mobile Phone Type of Respondent and Using Mobile Condition before Joining with Micro-Credit Organizations

Table 7. Distribution of Respondents by Telecommunication Condition Before and After Joining Micro-credit Organizations

Present Mobile Phone Type of Respondents * Condition of usages of mobile phone before joining Micro-credit organizations Cross tabulation

\begin{tabular}{|c|c|c|c|c|c|c|c|}
\hline \multirow[t]{2}{*}{ Count } & & \multicolumn{5}{|c|}{$\begin{array}{l}\text { Using mobile condition before joining with } \\
\text { Micro-credit organizations }\end{array}$} & \multirow{2}{*}{ Total } \\
\hline & & $\begin{array}{c}\text { No } \\
\text { operator }\end{array}$ & GP & BL & GP, BL & $\begin{array}{l}\text { GP,BL,R } \\
\text { OBI }\end{array}$ & \\
\hline \multirow{5}{*}{$\begin{array}{l}\text { Present Mobile phone } \\
\text { Type Of Respondent }\end{array}$} & No operator & 4 & 1 & 0 & 0 & 0 & 5 \\
\hline & GP & 14 & 48 & 0 & 0 & 0 & 62 \\
\hline & $\mathrm{BL}$ & 1 & 0 & 1 & 0 & 0 & 2 \\
\hline & GP, BL & 2 & 0 & 0 & 2 & 0 & 4 \\
\hline & GP,BL,ROBI & 0 & 0 & 0 & 0 & 1 & 1 \\
\hline Total & & 21 & 49 & 1 & 2 & 1 & 74 \\
\hline
\end{tabular}

We want to test the hypothesis

$H_{0}$ : There is no impact on relation of the present mobile phone type of respondents and condition of usages of mobile phone before joining Micro-credit organizations.

Vs $H_{1}: H_{0}$ is not true.

Chi-Square Tests

\begin{tabular}{cccc}
\hline & Value & df & Asymp. Sig. (2-sided) \\
\hline Pearson Chi-Square & $1.581 \mathrm{E} 2$ & 16 & .000 \\
Likelihood Ratio & 45.403 & 16 & .000 \\
Linear-by-Linear Association & 71.611 & 1 & .000 \\
N of Valid Cases & 74 & & \\
\hline
\end{tabular}

Interpretation: From above table we see that at 5\% level of significance Chi-Square is less than 0.05 . So, the null hypothesis is rejected. That is, there is an impact on relation of the present mobile phone type of respondent and respondents and condition of usages of mobile phone before joining micro-credit organizations.

9.8 The Distribution of Respondents by Present Home Type of Respondent and Home Type Condition before Joining with Micro-Credit Organizations

In our study we get the distribution of respondents by present home type of respondent and home condition before joining micro-credit organizations. 
Table 8. Distribution of respondents by present home type of respondents and home condition before joining micro-credit organizations

Present Home Type of Respondent * Home Type condition before joining Micro-credit organizations Cross tabulation

\begin{tabular}{c|c|c|c|c|c|c}
\hline \multirow{2}{*}{ Count } & \multicolumn{3}{|c|}{ Home Type condition before joining with } & Total \\
& & \multicolumn{3}{|c|}{ Micro-credit organizations } \\
\hline & & Bamboo & Bamboo and Tin & Soil & Bricks & \\
\hline \multirow{2}{*}{$\begin{array}{c}\text { Present Home Type } \\
\text { of Respondent }\end{array}$} & Bamboo & 7 & 0 & 0 & 0 & 7 \\
\cline { 2 - 8 } & Bamboo and Tin & 8 & 45 & 0 & 0 & 53 \\
\cline { 2 - 8 } & Soil & 0 & 0 & 6 & 0 & 6 \\
\cline { 2 - 8 } & Bricks & 0 & 2 & 0 & 6 & 8 \\
\hline \multicolumn{2}{c}{ Total } & 15 & 47 & 6 & 6 & 74 \\
\hline
\end{tabular}

We want to test the hypothesis

$H_{0}$ : There is no impact on relation of the present home type of respondent and home condition before joining with micro-credit organizations.

$H_{1}: H_{0}$ is not true.

Chi-Square Tests

\begin{tabular}{lccc}
\hline & Value & df & Asymp. Sig. (2-sided) \\
\hline Pearson Chi-Square & $1.569 \mathrm{E} 2$ & 9 & .000 \\
Likelihood Ratio & 96.866 & 9 & .000 \\
Linear-by-Linear Association & 51.341 & 1 & .000 \\
N of Valid Cases & 74 & & \\
\hline
\end{tabular}

Interpretation: From above table we see that at 5\% level of significance Chi-Square is less than 0.05 . So, the null hypothesis rejected. That is, there is an impact on relation of the present home type of respondent and home condition before joining micro-credit organizations.

9.9 The Distribution of Respondents by Present Primary Faith for Treatments of Respondent and Primary Faith for Treatments before Joining with Micro-Credit Organizations

In our study we get the distribution of respondents by present primary faith for treatment of respondent and primary faith for treatment before joining with micro-credit organizations.

Present Primary faith for treatment of respondent's Primary faith for treatment of respondents before joining Micro-credit organizations Cross tabulation

\begin{tabular}{ccccc}
\hline \multicolumn{1}{c}{ Count } & & $\begin{array}{c}\text { Primary faith for treatment of respondents } \\
\text { before joining with Micro-credit } \\
\text { organizations }\end{array}$ & Total \\
\cline { 1 - 3 } Present Primary faith for & Quack & Quack & Village Doctors & 2 \\
treatment of respondents & Village Doctors & 2 & 0 & 70 \\
\\
Total & MBBS & 0 & 66 & 2 \\
\hline
\end{tabular}

We want to test the hypothesis

$H_{0}$ : There is no impact on relation of the present primary faith for treatment of respondent and primary faith for treatment before joining micro-credit organizations.

$H_{1}: H_{0}$ is not true.

Chi-Square Tests

\begin{tabular}{lccc}
\hline & Value & df & Asymp. Sig. (2-sided) \\
\hline Pearson Chi-Square & 23.382 & 2 & .000 \\
Likelihood Ratio & 10.983 & 2 & .004 \\
Linear-by-Linear Association & 13.240 & 1 & .000 \\
N of Valid Cases & 74 & & \\
\hline
\end{tabular}

Interpretation: From above table we see that at 5\% level of significance Chi-Square is less than 0.05 . So, the null hypothesis is rejected. That is, there is an impact on relation of the present primary faith for treatment of respondent and primary faith for treatment before joining micro-credit organizations. 
9.10 The Distribution of Respondents by Present Sanitation Condition of Respondent and Sanitation Condition before Joining with Micro-Credit Organizations

In our study we get the distribution of respondents by Present Sanitation Condition of Respondent and Sanitation Condition before joining with Micro-credit organizations

Present Sanitation or respondent * Sanitation condition before joining Micro-credit organizations Cross tabulation

\begin{tabular}{cccc}
\hline Category & \multicolumn{2}{c}{$\begin{array}{c}\text { Sanitation condition before } \\
\text { joining with Micro-credit } \\
\text { organizations }\end{array}$} & \multirow{2}{*}{ Total } \\
\cline { 1 - 2 } Before taking loan & $\begin{array}{c}\text { No sanitary } \\
\text { latrine }\end{array}$ & $\begin{array}{c}\text { Having } \\
\text { sanitary latrine }\end{array}$ & \\
After taking loan & 10 & 0 & 10 \\
\hline
\end{tabular}

We want to test the hypothesis

$H_{0}$ : There is no impact on relation of the Present Sanitation Condition of Respondent and Sanitation Condition before joining Micro-credit organizations

Vs $H_{1}: H_{0}$ is not true.

Chi-Square Tests

\begin{tabular}{lccccc}
\hline & Value & Df & $\begin{array}{c}\text { Asymp. Sig. } \\
(2 \text {-sided })\end{array}$ & $\begin{array}{c}\text { Exact Sig. } \\
(2 \text {-sided })\end{array}$ & $\begin{array}{c}\text { Exact Sig. } \\
\text { (1-sided })\end{array}$ \\
\hline Pearson Chi-Square & 29.182 & 1 & .000 & & \\
$\begin{array}{l}\text { Continuity Correction } \\
\text { Likelihood Ratio }\end{array}$ & 25.249 & 1 & .000 & & \\
$\begin{array}{l}\text { Fisher's Exact Test } \\
\text { Linear-by-Linear Association }\end{array}$ & 29.548 & 1 & .000 & .000 & .000 \\
$\quad$ & 28.787 & 1 & .000 & & \\
\hline
\end{tabular}

Interpretation: From above table we see that at $5 \%$ level of significance Chi-Square is less than 0.05 . So, the null hypothesis is rejected. That is, there is an impact on relation of the Present Sanitation Condition of Respondent and Sanitation Condition before joining Micro-credit organizations.

9.11 The Distribution of Respondents by Relation with Micro-Credit of Respondent Family and Total Land of the Respondents (in Acre)

In our study we get the distribution relation with micro-credit of respondent family and total land of the respondents (in Acre).

Relation with Micro-Credit of Respondent Family * Total land of the respondents (in Acre) Cross tabulation

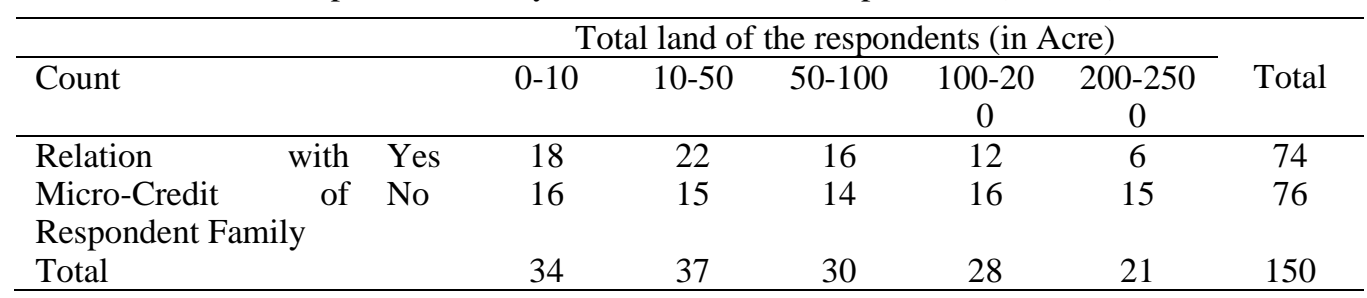

We want to test the hypothesis

$H_{0}$ : There is no impact on relation with micro-credit of respondent family and total land of the respondents (in Acre)

Vs $H_{1}: H_{0}$ is not true.

Chi-Square Tests

\begin{tabular}{cccc}
\hline & Value & df & Asymp. Sig. (2-sided) \\
\hline Pearson Chi-Square & 5.978 & 4 & .201 \\
Likelihood Ratio & 6.115 & 4 & .191 \\
Linear-by-Linear & 4.020 & 1 & .045 \\
Association & & & \\
No of Valid Cases & 150 & &
\end{tabular}

Interpretation: From above table we see that at 5\% level of significance Chi-Square is greater than 0.05 . So, the null hypothesis is accepted. That is, there is no impact on the relation with micro-credit of respondent family and total land of the respondents (in Acre). 
9.12 The Distribution of Respondents by Profession of Respondent and Objectives of Taking this Loan

In our study we get the distribution by profession of respondents and objectives of taking this loan.

Profession of Respondent * Objectives Of taking this loan Cross tabulation

\begin{tabular}{|c|c|c|c|c|c|c|c|c|}
\hline \multirow[t]{2}{*}{ Count } & & \multicolumn{6}{|c|}{ Objectives Of taking loans } & \multirow[t]{2}{*}{ Total } \\
\hline & & & Business & Food & Agriculture & Daughter Marriage & Treatment & \\
\hline & Farmer & 1 & 8 & 9 & 6 & 0 & 0 & 24 \\
\hline Profession & Labor & 0 & 7 & 12 & 1 & 1 & 1 & 22 \\
\hline & Businessman & 0 & 7 & 3 & 2 & 0 & 0 & 12 \\
\hline Responde & Teacher & 0 & 1 & 2 & 1 & 0 & 0 & 4 \\
\hline nt & Tailor & 0 & 1 & 0 & 1 & 0 & 0 & 2 \\
\hline & Housewife & 0 & 5 & 2 & 3 & 0 & 0 & 10 \\
\hline & Total & 1 & 29 & 28 & 14 & 1 & 1 & 74 \\
\hline
\end{tabular}

We want to test the hypothesis

$H_{0}$ : There is no impact on relation with profession of respondent and objectives of taking this loan.

Vs $H_{1}: H_{0}$ is not true.

Chi-Square Tests

\begin{tabular}{cccc}
\hline & Value & df & Asymp. Sig. (2-sided) \\
\hline Pearson Chi-Square & 17.564 & 25 & .029 \\
Likelihood Ratio & 19.138 & 25 & .000 \\
Linear-by-Linear & .029 & 1 & .045 \\
Association & & &
\end{tabular}

Association

$\mathrm{N}$ of Valid Cases 74

Interpretation: From above table we see that at 5\% level of significance Chi-Square is less than 0.05 . So, the null hypothesis is accepted. That is there is an impact on profession of respondent and objectives of taking this loan.

\section{Regression Analysis}

10.1 Multiple Regression Analysis on the Factors Related to Micro-Credit

\begin{tabular}{|c|c|c|c|c|c|}
\hline \multicolumn{6}{|c|}{ Coefficients } \\
\hline \multirow{2}{*}{ Model } & \multicolumn{2}{|c|}{ Unstandardized Coefficients } & \multirow{2}{*}{$\begin{array}{c}\text { Standardized Coefficients } \\
\text { Beta }\end{array}$} & \multirow[t]{2}{*}{$\mathrm{t}$} & \multirow{2}{*}{ Sig. } \\
\hline & $\beta$ & Std. Error & & & \\
\hline (Constant) & 1.931 & .235 & & 8.224 & .000 \\
\hline Gender of Respondent & .078 & .097 & .053 & .804 & .034 \\
\hline Profession of Respondent & -.007 & .020 & -.025 & -.367 & .714 \\
\hline Smoking behavior & .053 & .054 & .052 & .986 & .326 \\
\hline Family Size & -.030 & .018 & -.093 & -1.633 & .005 \\
\hline $\begin{array}{l}\text { Highest Education Level For Male } \\
\text { Member }\end{array}$ & -.050 & .027 & -.126 & -1.856 & .026 \\
\hline $\begin{array}{lll}\text { Highest Education } & \text { Level } & \text { For } \\
\text { Female Member } & & \\
\end{array}$ & -.001 & .025 & -.003 & -.055 & .957 \\
\hline $\begin{array}{l}\text { Meals On a Day taken By Each } \\
\text { Family }\end{array}$ & -.004 & .014 & -.013 & -.283 & .778 \\
\hline Family is Joint or Not & .016 & .061 & .016 & .269 & .788 \\
\hline Objectives of taking this loans & -.348 & .023 & -.772 & -15.408 & .000 \\
\hline Age of the Respondent & -.006 & .025 & -.011 & -.240 & .811 \\
\hline $\begin{array}{l}\text { Income of the Respondent( Tk. per } \\
\text { month) }\end{array}$ & .057 & .036 & .160 & 1.613 & .109 \\
\hline $\begin{array}{l}\text { Saving of the Respondent( Tk. per } \\
\text { month) }\end{array}$ & -.058 & .046 & -.132 & -1.263 & .209 \\
\hline $\begin{array}{l}\text { Total land of the respondents ( in } \\
\text { Acre ) }\end{array}$ & .084 & .044 & .229 & 1.935 & .035 \\
\hline $\begin{array}{l}\text { Cultivation land of the respondents } \\
\text { ( in Acre ) }\end{array}$ & -.035 & .046 & -.093 & -.765 & .446 \\
\hline
\end{tabular}

Regression Equation:

$\mathrm{Y}=\mathrm{a}+\mathrm{b}_{1} \mathrm{X}_{1}+\mathrm{b}_{2} \mathrm{X}_{2}+\mathrm{b}_{3} \mathrm{X}_{3}+\mathrm{b}_{4} \mathrm{X}_{4}+\mathrm{b}_{5} \mathrm{X}_{5}+\mathrm{b}_{6} \mathrm{X}_{6}+\mathrm{b}_{7} \mathrm{X}_{7}+\mathrm{b}_{8} \mathrm{X}_{8}+\mathrm{b}_{9} \mathrm{X}_{9}+\mathrm{b}_{10} \mathrm{X}_{10}+\mathrm{b}_{11} \mathrm{X}_{11}+\mathrm{b}_{12} \mathrm{X}_{12}+\mathrm{b}_{13} \mathrm{X}_{13}$

Where,

$\mathrm{X}_{1}=$ Gender of Respondents

$\mathrm{X}_{2}=$ Profession of Respondents 
$\mathrm{X}_{3}=\quad$ Smoking Behavior of Respondents

$\mathrm{X}_{4}=$ Family Size

$X_{5}=$ Highest Education Level of Male Member

$\mathrm{X}_{6}=$ Highest Education Level of Female Member

$\mathrm{X}_{7}=\quad$ Meals Taken Per Day by Each Family

$\mathrm{X}_{8}=$ Objectives of Taking Loan

$\mathrm{X}_{9}=$ Age of the Respondents

$\mathrm{X}_{10}=$ Income of the Respondents (Tk. per month)

$X_{11}=$ Saving of the Respondents (Tk. per month)

$\mathrm{X}_{12}=$ Total Land of the Respondents (in Acre)

$\mathrm{X}_{13}=$ Cultivable Land of the Respondents (in Acre)

Interpretation:

The intercept value of $(\mathrm{a}=1.931)$ indicates that the regression equation intersects the $\mathrm{Y}$ exists 1.931 when independent variables $\mathrm{X}_{1}, \mathrm{X}_{2}, \mathrm{X}_{3}, \mathrm{X}_{4}, \mathrm{X}_{5}, \mathrm{X}_{6}, \ldots \ldots \ldots, \mathrm{X}_{13}$ are zero.

Gender of Respondents: Coefficient of gender of respondents is .053 , that means if gender of respondents increases by one unit then on an average the relation with micro-credit will increase by .053 holding other things constant.

Profession of Respondents: Coefficient of profession of respondents is -.025 , that means if respondents have good profession compared to earlier profession on an average the relation with micro-credit activities will be found less by .025 , holding other things constant.

Smoking Behavior of Respondents: Coefficient of smoking behavior of respondents is .052. that means, if smoking behavior of respondents increases by one unit then on an average the relation with micro-credit will be increased by .052 holding other things constant.

Family Size: Coefficient of family size is -.093 , that means if family size increases by one unit then on an average the relation with micro-credit will be decreased by -.093 , holding other things constant.

Highest Education Level of Male Members: Coefficient of highest education level of male member is -.126, that means if highest education level of male members increases by one unit then on an average the relation with micro-credit will be decreased by .126 holding other things constant.

Highest Education Level of Female Members: Coefficient of highest education level for female members is -.003, that means if highest education level for female member increases by one unit then on an average the relation with micro-credit will be decreased by .003 holding other things constant.

Meals Taken Per Day by Each Family: Coefficient of meals taken in a day by each family is -.013. That means, if meals on a day taken by each family is increase by one unit then on an average the relation with micro-credit will decreased by .013 , remaining other things constant.

Objectives of Taking Loan: Coefficient of objectives of taking loan is -.772, that means if objectives of taking loan increase by one unit then on an average the relation with micro-credit will be decreased by .772 , holding other things constant.

Age of the Respondents: Coefficient of age of the respondents is -.011. That means, if the age of the respondents increases by one unit then on an average the relation with micro-credit will be decreased by .011 holding other constant.

Income of the Respondents (Tk. per month): Coefficient of income of the respondents (Tk. per month) is .160, that means if income of the respondents (Tk. per month) increases by one unit then on an average the relation with micro-credit will be increased by .160 holding other things constant.

Savings of the Respondents (Tk. per month): Coefficient of saving of the respondents (Tk. per month) is -.132, that means if saving of the respondents (Tk. per month) increases by one taka then on an average the relation with micro-credit will decreased by .132 holding other constant.

Total land of the respondents (in Acre): Coefficient of total land of the respondents (in Acre) is .229, that means if the total land of the respondents (in Acre) is increase by one unit then on an average the relation with micro-credit will increased by .229 , holding other constant.

Cultivable land of the respondents (in Acre): Coefficient of cultivation land of the respondents (in Acre) is -.093, that means if cultivation land of the respondents (in Acre) is increase by one unit then on an average the relation with 
micro-credit will decreased by -.093 , holding other constant.

10.2 Determination of the Value of $\boldsymbol{R}^{2}$

\begin{tabular}{lcccc}
\hline \multicolumn{4}{c}{ Model Summary } \\
\hline Model & $\mathrm{R}$ & R Square & Adjusted R Square & Std. Error of the Estimate \\
& .852 & .726 & .695 & .277 \\
\hline
\end{tabular}

a. Predictors: (Constant), Cultivativable land of the respondents ( in Acre ), Objectives Of taking this loan, Family size, Meals per day taken by each family, Smoking behavior, Age of the respondents, Highest education level for male members, Profession of respondents, Income of the respondents ( Tk. per month), Family is Joint or Not, Gender of respondents, Highest education level for male members, Savings of the respondents ( Tk. per month), Total land of the respondents ( in Acre ).

From the table,

$\mathrm{R}^{2}=\mathrm{SSR} / \mathrm{SST}=.726=72.6 \%$

Where,

SSR=Sum of Square of Regression

SST=Sum of Square of Total

Interpretation: $72.6 \%$ of the variation in the dependent variable $\mathrm{Y}$ (Relation with micro-credit) is explained by the variation in the independent variables i.e.; Cultivable land of the respondents ( in Acre ), Objectives Of taking these loan, Family Size, Meals per day taken by each family, Smoking behavior, Age of the respondents, Highest education level for male members, Profession of respondents, Income of the respondents ( Tk. per month), Family is Joint or Not, Gender Of respondents, Highest education level for male members, Savings of the respondents ( Tk. per month), Total land of the respondents ( in Acre ).

10.3 Multiple Regression Analysis on the Improvements on Hosing Condition

10.3.1 Regression Analysis

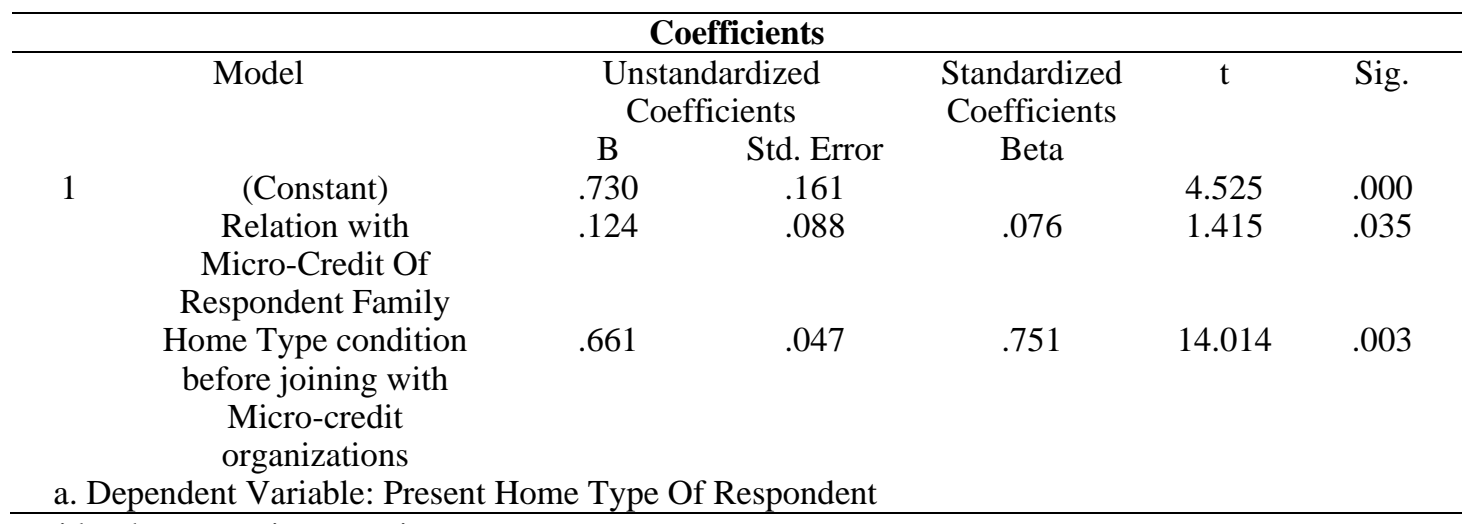

Let us consider the regression equation,

$Y=A+\beta_{1} X_{1}+\beta_{2} X_{2}$

Where,

$X_{1}=$ Relation with Micro-credit of Respondent Family

$X_{2}=$ Home Type condition before joining with Micro-credit organization

$Y=$ Present Home Type of Respondent

Interpretation: The intercept value of $(a=.730)$ indicates that the regression equation intersects the $\mathrm{Y}$ exist .730 when independent variables X1 and X2 are zero.

Relation with Micro-credit of Respondent Family: Coefficient of relation with micro-credit of respondent family is .124 that means if relation with micro-credit of respondent family is increase by one unit then on an average the present home type of respondent will increased by .124 holding other constant.

Home Type condition before joining Micro-credit organizations: Coefficient of home type condition before joining with micro-credit organizations is .661 that means if home type condition before joining with micro-credit organizations is increase by one unit then on an average the present home type of respondent will increased by .661 holding other constant. 
Since all the $\mathrm{P}$ values of all independent variables are less than .05 , we can say that all the independent variables are significant. So, the model is valid.

So, the model is,

$Y=A+\beta_{1} X_{1}+\beta_{2} X_{2}$

10.4 Determination of $\boldsymbol{R}^{2}$

\begin{tabular}{llrrr}
\hline \multicolumn{5}{c}{ Model Summary } \\
\hline Model & $\mathrm{R}$ & $\mathrm{R}$ Square & Adjusted R Square & Std. Error of the Estimate \\
1 & $.918^{\mathrm{a}}$ & .843 & .841 & .531 \\
\hline
\end{tabular}

a. Predictors: (Constant), condition of homes before joining Micro-credit organizations, Relation with Micro-Credit of respondent family

From the table,

$\mathrm{R}^{2}=\mathrm{SSR} / \mathrm{SST}=.843=84.3 \%$

Where,

$\mathrm{SSR}=$ Sum of Square of Regression

SST $=$ Sum of Square of Total

Interpretation: $84.3 \%$ of the variation in the dependent variable $\mathrm{Y}$ (present home type of respondent) is explained by the variation in the independent variables i.e.; relation with micro-credit of respondent family, home type condition before joining with micro-credit organizations.

10.5 Multiple Regression Analysis on the Improvements on Treatment Condition

10.5.1 Regression Analysis in SPSS

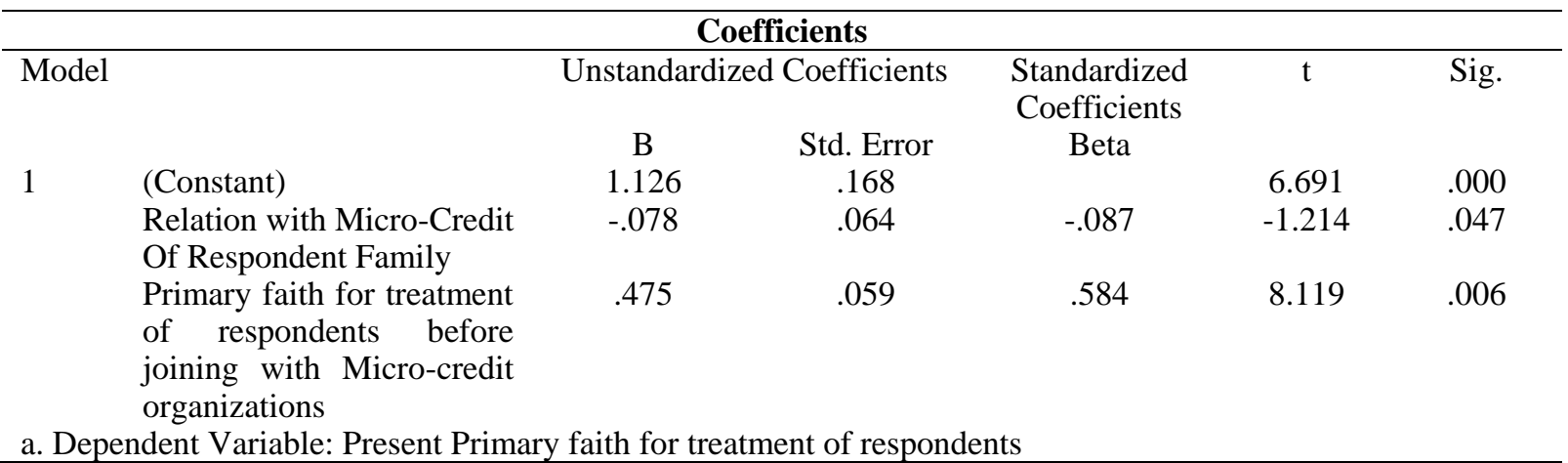

Let us consider the regression equation,

$Y=A+\beta_{1} X_{1}+\beta_{2} X_{2}$

Where,

$X_{1}=$ Relation with Micro-credit of Respondent Family

$X_{2}=$ Primary faith for treatment condition before joining with Micro-credit organizations

$Y=$ Present primary faith for treatment of respondent

Interpretation

The intercept value of $(\mathrm{a}=1.126)$ indicates that the regression equation intersects the $\mathrm{Y}$ exist 1.126 when independent variables $\mathrm{X} 1$ and $\mathrm{X} 2$ are zero.

Relation with Micro-credit of Respondent Family: Coefficient of relation with micro-credit of respondent family is -.078 that means if relation with micro-credit of respondent family is increase by one unit then on an average the present primary faith for treatment of respondent will decreased by .078 holding other constant.

Primary faith for treatment condition before joining with Micro-credit organizations: Coefficient of primary faith for treatment condition before joining with micro-credit organizations is .475 that means if primary faith for treatment condition before joining with micro-credit organizations is increase by one unit then on an average the present primary faith for treatment of respondent will increased by .475 holding other constant.

Since all the $\mathrm{P}$ values of all independent variables are less than .05 , we can say that all the independent variables are significant. Thus, the model is valid. 
The model is,

$Y=A+\beta_{1} X_{1}+\beta_{2} X_{2}$

10.6 Determination of $\boldsymbol{R}^{2}$

Model Summary

\begin{tabular}{lcccc}
\hline Model & R & R Square & Adjusted R Square & Std. Error of the Estimate \\
\hline 1 & $.879^{\mathrm{a}}$ & .773 & .769 & .35137 \\
\hline
\end{tabular}

a. Predictors: (Constant), Primary faith for treatment of respondents before joining with Micro-credit organizations, Relation with Micro-Credit of Respondent Family

From the table,

$\mathrm{R}^{2}=\mathrm{SSR} / \mathrm{SST}=.773=77.3 \%$

Where,

SSR $=$ Sum of Square of Regression

SST=Sum of Square of Total

Interpretation: $77.3 \%$ of the variation in the dependent variable $\mathrm{Y}$ (present primary faith for treatment of respondent) is explained by the variation in the independent variables i.e.; relation with micro-credit of respondent family, primary faith for treatment condition before joining with micro-credit organizations.

10.7 Multiple Regression Analysis on the Improvements on Telecommunication Condition

10.7.1 Regression Analysis in SPSS

\begin{tabular}{|c|c|c|c|c|c|c|}
\hline \multicolumn{7}{|c|}{ Coefficients } \\
\hline \multirow[t]{2}{*}{ Model } & & Unstandar & Coefficients & Standardized & $\mathrm{t}$ & Sig. \\
\hline & & $\beta$ & Std. Error & Beta & & \\
\hline \multirow{3}{*}{1} & (Constant) & 1.080 & .366 & & 2.950 & .004 \\
\hline & $\begin{array}{l}\text { Relation with Micro-Credit } \\
\text { Of Respondent Family }\end{array}$ & -.553 & .231 & -.003 & -2.391 & .018 \\
\hline & $\begin{array}{l}\text { Using mobile condition } \\
\text { before joining with }\end{array}$ & 1.000 & .001 & 1.000 & 872.732 & .043 \\
\hline Depe & $\begin{array}{l}\text { Micro-credit organizations } \\
\text { ident Variable: Present mobil }\end{array}$ & hone $\mathrm{T}$ & pondent & & & \\
\hline
\end{tabular}

Let us consider the regression equation,

$Y=A+\beta_{1} X_{1}+\beta_{2} X_{2}$

Where,

$X_{1}=$ Relation with Micro-credit of Respondent Family

$X_{2}=$ Usages of mobile condition before joining Micro-credit organization.

$Y=$ Current usages of mobile phone by Respondents

Interpretation

The intercept value of $(\mathrm{a}=1.080$ indicates that the regression equation intersects the $\mathrm{Y}$ exist 1.080 when independent variables $X_{1}$ and $X_{2}$ are zero.

Relation with Micro-credit of Respondent Family: Coefficient of relation with micro-credit of respondent family is -.553 that means if relation with micro-credit of respondent family is increase by one unit then on an average the present using mobile condition of respondent will have decreased by .553 holding other constant.

Usages of mobile condition before joining Micro-credit organization: Coefficient of usages of mobile condition before joining Micro-credit organization is 1.00 that means if using mobile condition before joining with micro-credit organizations is increase by one unit then on an average the present using mobile condition of respondent will have increased by 1.00 holding other constant.

Since all the $\mathrm{P}$ values of all independent variables are less than .05 , we can say that all the independent variables are significant. So, the model is valid

So, the model is,

$Y=A+\beta_{1} X_{1}+\beta_{2} X_{2}$ 
10.8 Determination of $\boldsymbol{R}^{2}$

Model Summary

\begin{tabular}{ccccc}
\hline Model & $\mathrm{R}$ & R Square & Adjusted R Square & Std. Error of the Estimate \\
\hline 1 & .947 & .897 & .895 & 1.410 \\
\hline
\end{tabular}

a. Predictors: (Constant), Usages of mobile condition before joining Micro-credit organization, Current usages of mobile phone by Respondents

From the table,

$\mathrm{R}^{2}=\mathrm{SSR} / \mathrm{SST}=.843=84.3 \%$

Where,

$\mathrm{SSR}=\mathrm{Sum}$ of Square of Regression

SST=Sum of Square of Total

Interpretation: $84.3 \%$ of the variation in the dependent variable Y (present using mobile condition of respondent) is explained by the variation in the independent variables i.e.; relation with micro-credit of respondent family, usages of mobile phone before joining micro-credit organizations.

10.8.1 Global Test on the Set of Independent Variables (Testing The Multiple Regression Models)

Step-1:

$\mathrm{H}_{\mathrm{o}}: \beta_{1}=\beta_{2}=0$ (That is the model is invalid)

Vs $\mathrm{H}_{1}$ : Not all $\beta$ 's are zero (That is the model is valid)

Step-2: Here the level of significance is, $\alpha=.05$

Step-3: F-test statistic will be used here.

Step-4: Decision rule: If $\mathrm{P}$-value $<\alpha$-value, $\mathrm{H}_{\mathrm{o}}$ will be rejected

If $\mathrm{P}$-value $>\alpha$-value, $\mathrm{H}_{\mathrm{o}}$ will be accepted

Step-5: Calculation and Decision Making.

\begin{tabular}{llccccc}
\hline \multicolumn{7}{c}{ ANOVA } \\
\hline Model & & Sum of & df & Mean Square & F & Sig. \\
\cline { 3 - 7 } 1 & Squares & & & & \\
& Regression & 1524120.684 & 2 & 762060.342 & $3.831 \mathrm{E} 5$ & .001 \\
& Residual & 292.390 & 147 & 1.989 & & \\
& Total & 1524413.073 & 149 & & & \\
\hline
\end{tabular}

a. Predictors: (Constant), usages of mobile phone before joining micro-credit organizations, Relation with Micro-Credit of Respondent Family

b. Dependent Variable: Present Mobile Phone Type of Respondent

Interpretation: Since p-value $(.001)<\alpha$-value $(.05), H_{o}$ is rejected and $H_{1}$ is accepted. That is at least one variable has significance effect. This means that the regression model is valid. That is the independent variables have enough capability to estimate the present using mobile condition of respondents.

1. About $80 \%$ of all Hindus are relates with micro-credit organizations.

2. There is no relation of profession to relate with micro-credit because, all professional people relate to improve their conditions.

3. There is a relation of micro-credit with total land of respondent families that who's have less land they are relate mostly with micro-credit organizations.

\section{Conclusion}

The goal of this research was to find out the impact of micro credit on the improvement of living standards of poor people in society. The analysis of data using the survey that most of the respondents started their task by taking loan from the microcredit institutions. They were able to increase their income, and this impacted not only on their income but also demonstrated positive impact on other factors of daily life. The results obtained from our analysis regarding the success of increasing their living standard. It was found from our observation that most of the family members of borrowers contributed to run the business directly or indirectly, unrelated to the matter that which member was sanctioned the loan. To sum up, it can be noticed from our overall analysis that there was significant impact of microfinance activities on improvement of the living standard of the family not only in economic term but also in social 
term.

\section{References}

Chowdhury, M. J. A. (2000). Microcredit, Enhancement of Entitlement and Alleviation of Poverty: An Investigation into the Grameen Bank's Role in Bangladesh.

Hossain, M. (1984). Credit for the Rural Poor, The experience of Grameen Bank in Bangladesh, Research Monotable No. 4, BIDS, Dhaka.

Islam, A. (2008). Who Benefits from Microfinance? The Impact Evaluation of Large Scale Programs in Bangladesh, Discussion Paper 29/08, ISSN 1441-5429, Department of Economics, Monash University Clayton Vic 3800 Australia

Khandker, R. S. (2003). Micro-finance and Poverty: Evidence Using Panel Data from Bangladesh, World Bank Policy Research Working Paper 2945, Washington, USA,

Khandker, S. R., Khalily, B., \& Khan, Z. (1995). Credit Program for the Poor; Households and Interhouseholds Impacts and Program Sustainability by BIDS and the World Bank.

Latif, M. A. (2001). Microcredit and Savings of Rural Householdss in Bangladesh, Bangladesh Development Studies, 27(1), 51-71.

Oxford poverty and human development Initiative(OPHI) 2013.

Rahman, A. (1999). Microcredit Initiatives for Equitable and Sustainable Development: Who Pays?" World Development, 27(2), 67-82. https://doi.org/10.1016/S0305-750X(98)00105-3

Roy, D. (2012). Development Economics, Oxford University press. https://doi.org/10.1057/9781137336583.0404

Second Five Year Plan (SFYP).

Yunus, M. (1999). Banker to the Poor: Micro-lending and the Battle Against World Poverty, New York: Public Affairs

\section{Copyrights}

Copyright for this article is retained by the author(s), with first publication rights granted to the journal.

This is an open-access article distributed under the terms and conditions of the Creative Commons Attribution license which permits unrestricted use, distribution, and reproduction in any medium, provided the original work is properly cited. 